\title{
Evaluation of Genetic Diversity of African Eggplant [Solanum aethiopicum (L.) sub sp Kumba] Using EST-SSR Molecular Markers
}

\author{
Sawadogo Boureima*, Kiebre Zakaria, Bationo-Kando Pauline, Kiebre Mariam, \\ Traore R. Ernest, Sawadogo Nerbéwendé, Nanema K. Romaric, Ouedraogo M. Hamed, \\ Kabore Boukaré, Alleidi Issa et and Sawadogo Mahamadou
}

Laboratoire Biosciences, Unité de Formation et de Recherche en Sciences de la Vie et de la
Terre, Université de Ouagadougou, 03 BP7021 Ouagadougou 03, Burkina Faso

*Corresponding author

\section{A B S T R A C T}

\section{Keywords}

Kumba, Solanum aethiopicum,

Molecular diversity, Burkina Faso

\section{Article Info}

Accepted:

24 January 2018

Available Online:

10 February 2018
African eggplant (Solanum aethiopicum L.) is an important vegetable grown for it leaves and fruits in tropical regions. At Burkina Faso, Kumba group is widely used for food and traditional physic. It's also income source for majority population. Despite, its socioeconomic importance, there is a few scientific knowledge on its genetic diversity. The objective of this study is to evaluate genetic diversity of Kumba group. For this, a molecular characterization of forty-nine (49) accessions collected in the three climatic zones was carried out. The analysis of diversity used EST-SSRs molecular markers revealed moderate genetic variability within the collection, structured into three molecular groups. Indeed, 19 of the 29 markers tested were polymorphic. Expected heterozygosity $\left(\mathrm{H}_{\mathrm{e}}\right)$ for the all collection ranged from 0.075 for smSSR41 marker to 0.507 for smSSR27 and smSSR35 markers. The Shannon diversity index (I), it ranged from 0.163 for smSSR41 marker to 1.307 for smSSR09 marker. The organization of this genetic diversity is weakly influenced by the climatic zone.

\section{Introduction}

African eggplant (Solanum aethiopicum L.) has four cultivars groups (Aculeatum, Shum, Gilo and Kumba). At Burkina Faso, Kumba groups were mainly cultivated and occupied an important place in the food habits of the populations. It's the one cultivation grown widely for its leaves and fruit and is very spread in tropical regions. In fact, the leaves and fruits of Kumba are eaten under many forms raw, as ragout and used for flavor. (Daunay et al., 1998; Adeniji and Aloyce,
2012 and Bationo-Kando et al., 2015a) were reported that, it's also used in traditional physic for the treatment of several diseases (diarrhea, vomiting, cholera, hypertension, scorpion and bee stings). Its cultivation is income source for local populations. In view of its socio-economic importance, studies have been carried out in order to lay the foundations for its genetic improvement (Bationo-Kando et al., 2015a, Sawadogo et al., 2016). Unfortunately, most of these studies don't cover the whole territory or were conducted with phenotypic markers that are influenced 
by environment factors. The single diversity study using molecular markers was performed by Bationo-Kando et al., (2015b) but only concerns accessions from west region. The present study aims to evaluate the genetic diversity of Kumba's accessions from the three climatic zones of Burkina Faso using molecular markers. Specifically, this involves determining the level and organization of Kumba's genetic diversity using EST-SSR (Simple Sequence Repeat) markers.

\section{Materials and Methods}

\section{Plant material}

Forty-nine (49) local accessions from three climate zones of Burkina Faso were used in this study, which eighteen (18) from Sahelian zone, twenty-one (21) from Sudano-Sahelian zone and ten (10) from Sudanian zone. Three varieties (Meketan, N'Goyo and KeurM'BirN'Dao) were also used. These accessions were sown and grown in a greenhouse in some pots. Always, the pots were regularly watered on morning and evening finally to sure good growth of pant development of seedlings during the test (1 month). The young leaves of each accession were removed, weighed immediately and used for of genomic DNA extraction.

\section{Methods}

\section{Genomic DNA extraction}

Genomic DNA extraction was conducted at Molecular Biology Unit of Plant Genetics and Improvement Team of University Ouaga I Pr Joseph KI-ZERBO. Young leaves were harvested from 20 days old plants. DNA was extracted from $0.4 \mathrm{~g}$ of fresh leaves following by "CTAB" method of Doyle and Doyle1990adapted to Kumba. Briefly, leaves were ground using a mortar and pestle and dissolved in Tris EDTA Sorbitol (TES). The samples were centrifugeted at $10,000 \mathrm{rpm}$ and $4^{\circ} \mathrm{C}$ for 10 minutes. A volume of $1000 \mu \mathrm{l}$ of $\mathrm{CTAB}$ at $60^{\circ} \mathrm{C}$ was added in each sample and all samples were placed during three hours to half in water bath at $60^{\circ} \mathrm{C}$ before centrifugation. Thus, a volume of $750 \mu \mathrm{l}$ of CIAA (chloroform-isoamyl alcohol) was added in each sample and all samples were centrifugated during 15 minutes at 10,000 rpm and $4^{\circ} \mathrm{C}$.After first centrifugation, the float was collected and put in somenew tubes next a volume of isopropanol at $-20{ }^{\circ} \mathrm{C}$ was added in each sample. Newly, the tubes were centrifuged again during 10 minutes at 10,000 rpm and $4{ }^{\circ} \mathrm{C}$. The pellets of DNA were rinsed with $70 \%$ ethanol and centrifugated during 10 minutes at $10,000 \mathrm{rpm}$. After centrifugation, the floats were removed and cooled at room temperature. The DNA pellets of samples were dissolved in $150 \mu \mathrm{l}$ of Tris EDTA and put in freezer at $-20{ }^{\circ} \mathrm{C}$.

\section{EST-SSR marker}

Twenty-nine (29) EST-SSRs markers used to study for genetic diversity of Kumba. These markers are the same used by Tümbilen et al., in 2011 (Table 1).

\section{PCR amplification}

PCR amplification performed in $20 \mu \mathrm{l}$ composed of $2 \mu \mathrm{l}$ of genomic DNA diluted to $200 \mathrm{X}(5 \mu \mathrm{g} / \mu \mathrm{l}), 1 \mu \mathrm{l}$ of $\mathrm{F}$ and $\mathrm{R}$ primers, 0.5 $\mu \mathrm{l}$ of dNTP, $2.5 \mu \mathrm{l}$ of buffer, $0.2 \mu \mathrm{L}$ of Taq polymerase $(1 \mathrm{U})$, and $13.8 \mu \mathrm{L}$ ultra-pure water. After homogenization, the tubes were placed in a thermocycler for amplification. The PCR program was as follows: Initial denaturation at $94{ }^{\circ} \mathrm{C}$ for $5 \mathrm{~min}$, followed by 27 cycles of $94{ }^{\circ} \mathrm{C}$ for $30 \mathrm{~s}$, hybridization at temperature $\left({ }^{\circ} \mathrm{C}\right)$ of $\mathrm{F}$ primer for $45 \mathrm{~s}$ and extension at $72{ }^{\circ} \mathrm{C}$ for $45 \mathrm{~s}$. After these cycles, secondly, 8 cycles were added of $94{ }^{\circ} \mathrm{C}$ for 30 $\mathrm{s}$, hybridization at temperature $\left({ }^{\circ} \mathrm{C}\right)$ of $\mathrm{R}$ primer for $45 \mathrm{~s}$ and an extension at $72{ }^{\circ} \mathrm{C}$ for 
45 s. A final elongation step at $72^{\circ} \mathrm{C}$, for 10 min. In fact, 35 cycles were carried in this PCR amplification at $4{ }^{\circ} \mathrm{C}$.

\section{Electrophoresis migration and bands reading}

The results of PCR amplification were separated by electrophoresis (2\% agarose gel with TBE) at 80 volts. The gels were stained with BET (Bromide Ethidium), used by standard methods of Sambrook et al., (1989) and statement under ultra violet (UV) light. The DNA ladder (Bioline $\mathrm{GmbH}$, Germany) was used in each gel as molecular size standard.

\section{Data analysis}

A binary matrix based on the presence (1) or absence (0) of bands on the gel was performed for profiles of electrophoresis analysis. Markers gave white bands were retained for statistical analysis. Three software packages were used (GenAlEx 6.501, Genetix 4.0.5.2, and Darwin 6.0.4). The genetic parameters were calculated using GenAlEx software in order to evaluate the level of diversity of all collection. The structure of the diversity was carried out with Darwin software. But the Genetix software was used to calculate the genetic distance between the genetic groups formed.

\section{Results and Discussion}

\section{Kumba's collection diversity}

Molecular characterization revealed moderate genetic diversity in Kumba's collection of Burkina Faso. Among twenty-nine (29) markers, nineteen (19) were polymorphic (Table 2). Thirty (30) alleles were identified with mean of 1.582 alleles per marker. For the number of effective alleles $\left(\mathrm{A}_{\mathrm{e}}\right)$ values of 1.080 for smSSR41 marker and 1.988 for markers smSSR16, smSSR21, smSSR27 and
smSSR35 with mean of 1.699 were determined. The value of expected heterozygosity $\left(\mathrm{H}_{\mathrm{e}}\right)$ for whole collection varied from 0.075 for smSSR41 marker to 0.507 for the smSSR27 and smSSR35 markers with mean of 0.355 . For all collection, the size of the alleles varies from $50 \mathrm{pb}$ to $450 \mathrm{pb}$. The Shannon diversity index (I) varied from 0.163 (smSSR41) to 1.307 (smSSR09). The polymorphism information content (PIC) varied from 0.074 for smSSR41 to 0.497 for the smSSR16, smSSR21, smSSR27 and smSSR35 markers.

Kumba's diversity according to the "climate zone"

The Analysis of Molecular Variance (AMOVA) according to Excoffier et al., (1992) showed that the factor "climatic zone" have a significant role in molecular variability expression (10\% of the total variance) in Kumba's collection (Table 3). The factor "accession" while came to $90 \%$ in variability expression. Significant differentiation indices $\left(\Phi_{P T}\right)$ were observed between accessions of different climatic zones. They varied from 0.087 (Sahelian and Sudano Sahelian zones) to 0.144 (Sudanian and Sudano-Sahelian zones). The genetic diversity parameters have variedthe one zone to another zone and were decreasing according to the north-south climatic gradient. In Sahelian zone, expected heterozygosity (0.354) the genetic parameters recorded and Shannon index (0.510) are higher than those of Sudano-sahelian and Sudanian zones. They were also higher in Sudano-Sahelian zone than in Sudanian zone (Table 4).

\section{Structuring of Kumba's diversity}

Genetic distances established for all accessions varied from 0.06 to 0.55 . This result shown that, there were the lowest amounts of variation among the accessions. 
Table.1 EST-SSRs markers used in this study (Tumbilen et al., 2011)

\begin{tabular}{|c|c|c|c|}
\hline Marker name & Forward Sequence & Reverse Sequence & $\operatorname{Tm}\left({ }^{\circ} \mathbf{C}\right)$ \\
\hline SmSSR01 & GTGACTACGGTTTCACTGGT & GATGACGACGACGATAATAGA & 55.1 \\
\hline smSSR03 & ATTGAAAGTTGCTCTGCTTC & GATCGAACCCACATCATC & 54.5 \\
\hline SmSSR04 & CTCTGCTTCACCTCTGTGTT & CCATGAAAGAGAAGATCGAG & 55.2 \\
\hline SmSSR09 & CACATGGGAACCTACTTACC & GACGACCATCAAACAAGAAT & 54.7 \\
\hline SmSSR11 & AAACAAACTGAAACCCATGT & AAGTTTGCTGTTGCTGCT & 54.5 \\
\hline smSSR12 & AAACAGAAACCAGAGTACTTCA & CAGAAGAAGGTTCAGTTTGC & 54.3 \\
\hline smSSR14 & ATACCACATCAATCCAAAGC & CATCATCATCTTCACAGTGG & 54.8 \\
\hline smSSR15 & CTGTGGTTGCCTTATCAGTA & TAGTCCAAGGGTTTGATGAC & 54.4 \\
\hline smSSR16 & AAGAATTTGATGTTGAACCG & CTTTATCAGCCAATTTCTGG & 55.1 \\
\hline SmSSR17 & TCTTGCCATTTAATTTCCTC & CTATGTCCCTATTATGCCCA & 54.8 \\
\hline smSSR18 & TTAGGCATTTGATTTAGCCT & TATGTCCCTAAGCATAACGG & 54.9 \\
\hline smSSR19 & GAACAATGATTCATCGGATT & AGTTGATGTTGAATTTCCCA & 55.2 \\
\hline SmSSR21 & AAGTTTACATGACAGCACCA & TTGCCATCATCAATACCATA & 54.4 \\
\hline smSSR22 & CTCCGTCAAATTCCTATCAA & GGGAGTCCACATAGAGCATA & 55.3 \\
\hline SmSSR24 & GATTTATGGCTTCTGATGGA & TCCTAACCCACTTGATGAAC & 55.1 \\
\hline smSSR27 & ATACATTTGAGCCGAGAGTG & TAAATCTGAGAAGGTCGCAT & 55.2 \\
\hline smSSR28 & САСАСТССТCAGAACTCCAT & CAGCAGTACCTCTTGGTCAT & 55.2 \\
\hline smSSR29 & TCCACTTCAATTTCCAAGTC & GATCGCTTAGCAGAAGCC & 55.7 \\
\hline SmSSR31 & СТTCСТАСССАСАСТТСАТС & TAGGCCGGAGATAGTTGTAA & 54.8 \\
\hline smSSR35 & CACCACCAAAGAATTCCTAA & TTGCTAGAAATAGCAAAGGG & 55.1 \\
\hline smSSR36 & AGCACCAGGACAATGAATAC & CCATTTCTTTCTCGACCTTA & 54.8 \\
\hline SmSSR37 & AAAGAAGCTTCCGACGAA & CACTTGTTTCAGCACTTTGA & 55.5 \\
\hline SmSSR40 & TTCTTTGATCTTCAATTCCAA & ATGAAGCTGTTCATGATTCC & 55.1 \\
\hline smSSR41 & СTCСTCCTGGTAAGGAGTCT & GCAGTATAGAGACGCGAAAT & 54.9 \\
\hline SmSSR42 & ACAGTACACCAGAAACGGAA & GTTACAATGACGGTGGATCT & 55.3 \\
\hline smSSR44 & TGCATTTCATACAGAAACCA & GCAAGGATATCACTGAGCTG & 55.5 \\
\hline smSSR45 & TTTCTCAACCCAAACTGAAC & GCAGCTCTCGCATAGATAGT & 55.2 \\
\hline smSSR46 & GGAAACCTTCATTCACTTCA & AGGTCACCGTTACAATTACG & 55.2 \\
\hline SmSSR47 & ACACGATGATCATAAGGGAG & ATCTAATCACTGTCGCTGCT & 55.1 \\
\hline
\end{tabular}

Table.2 Diversity of parameters of the 19 EST-SSRs markers
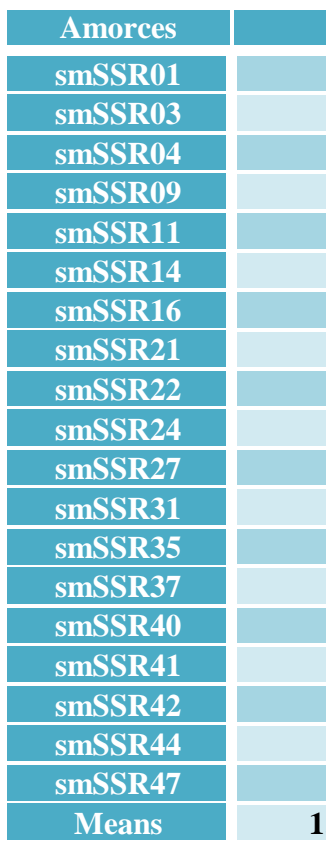

\begin{tabular}{|c|c|c|}
\hline $\mathbf{A}^{\mathbf{t}}$ & $\mathbf{A}_{\mathrm{e}}$ & $\mathbf{H}_{\mathrm{e}}$ \\
\hline 2 & 1.426 & 0.289 \\
\hline 2 & 1.720 & 0.395 \\
\hline 2 & 1.451 & 0.256 \\
\hline 2 & 1.899 & 0.471 \\
\hline 2 & 1.899 & 0.210 \\
\hline 2 & 1.827 & 0.268 \\
\hline 2 & 1.988 & 0.470 \\
\hline 2 & 1.988 & 0.416 \\
\hline 1 & 1.786 & 0.449 \\
1 & 1.696 & 0.419 \\
\hline 1 & 1.988 & 0.507 \\
\hline 2 & 1.964 & 0.383 \\
1 & 1.988 & 0.507 \\
\hline 1 & 1.210 & 0.177 \\
1 & 1.550 & 0.362 \\
\hline 1 & 1.080 & 0.075 \\
\hline 2 & 1.550 & 0.335 \\
\hline 2 & 1.451 & 0.290 \\
\hline 1 & 1.827 & 0.462 \\
\hline $\mathbf{1 . 5 8 0}$ & $\mathbf{1 . 6 9 9}$ & $\mathbf{0 . 3 5 5}$ \\
\hline
\end{tabular}

\begin{tabular}{|c|c|c|}
\hline I & PIC & P $(\%)$ \\
\hline 0.899 & 0.283 & 100 \\
\hline 1.142 & 0.387 & 100 \\
\hline 0.751 & 0.250 & 100 \\
\hline 1.307 & 0.461 & 100 \\
\hline 0.657 & 0.206 & 100 \\
\hline 0.808 & 0.263 & 100 \\
\hline 1.307 & 0.460 & 100 \\
\hline 1.194 & 0.407 & 100 \\
\hline 0.632 & 0.440 & 100 \\
\hline 0.601 & 0.410 & 100 \\
\hline 0.690 & 0.497 & 100 \\
\hline 1.122 & 0.375 & 100 \\
\hline 0.690 & 0.497 & 100 \\
\hline 0.317 & 0.173 & 100 \\
\hline 0.540 & 0.355 & 100 \\
\hline 0.163 & 0.073 & 100 \\
\hline 1.003 & 0.204 & 100 \\
\hline 0.888 & 0.284 & 100 \\
\hline 0.645 & 0.458 & 100 \\
\hline $\mathbf{0 . 8 0 8}$ & $\mathbf{0 . 3 4 1}$ & $\mathbf{1 0 0}$ \\
\hline
\end{tabular}

$\mathrm{A}^{\mathrm{t}}$ : total number of alleles, $\mathrm{A}_{\mathrm{e}}$ : number of efficient alleles, $\mathrm{H}_{\mathrm{e}}$ : expected heterozygosity, PIC: Polymorphism Information Content, I: Shannon diversity index, P: loci polymorphic percentage 
Table.3 Analysis of Molecular Variance (AMOVA) of accessions of the three climatic zones of Burkina Faso, with a $\mathrm{P}_{\text {value }}$ obtained after 999 permutations

\begin{tabular}{|l|c|c|c|c|c|}
\hline Source & df & SS & MS & Est. Var. & D\% \\
\hline Variance amongclimatic zones & 2 & 32.385 & 10.795 & 0.538 & $10 *$ \\
\hline Variance within climatic zones & 47 & 235.884 & 4.914 & 4.914 & 90 \\
\hline Total & 49 & 268.269 & & 5.452 & 100 \\
\hline
\end{tabular}

Statistics include: df, degrees of freedom; SS, sum of squares; MS, mean squares; Est. Var., estimated variance; and $\% \mathrm{D}$, distribution of total variance.

$* \mathrm{p}=0.0001$.

Table.4 Distribution of Kumba's genetic diversity following climatic zones

\begin{tabular}{|c|c|c|c|c|c|}
\multirow{2}{*}{ Climatic zones } & \multicolumn{2}{|c|}{$\begin{array}{c}\text { Intra climatic zones } \\
\text { Diversity }\end{array}$} & \multicolumn{2}{c|}{ Index of differentiation $\left(\Phi_{P T}\right)$} \\
\cline { 2 - 6 } & $\mathbf{H}_{\mathbf{e}}$ & $\mathbf{I}$ & Sahelian & S- Sahelian & Sudanian \\
\hline Sahelian & 0.354 & 0.510 & 0.000 & & \\
\hline S- Sahelian & 0.325 & 0.423 & $0.087^{*}$ & 0.000 & \\
\hline Sudanian & 0.290 & 0.399 & $0.113^{* *}$ & $0.144^{*} *$ & 0.000 \\
\hline
\end{tabular}

He: expected heterozygosity; I: Shannon diversity index; S-Sahelian: SudanoSahelian

Table.5 Distribution of Kumba genetic diversity of genetic groups

\begin{tabular}{|l|l|l|l|l|l|}
\hline Groups & $\mathrm{A}_{\mathrm{e}}$ & $\mathrm{H}_{\mathrm{e}}$ & $\mathrm{I}$ & $\mathrm{PIC}$ & $\mathrm{P}(\%)$ \\
\hline Group A & 1.592 & 0.361 & 0.513 & 0.348 & 100 \\
\hline Group B & 1.531 & 0.328 & 0.471 & 0.325 & 93.33 \\
\hline Group C & 1.485 & 0.307 & 0.404 & 0.267 & 70.00 \\
\hline Means & 1.536 & 0.332 & 0.462 & 0.313 & 87.78 \\
\hline
\end{tabular}

$\mathrm{A}_{\mathrm{e}}$ : number of efficient alleles, $\mathrm{H}_{\mathrm{e}}$ : expected heterozygosity, PIC: Polymorphism Information Content, I: Shannon diversity index, P: polymorphic loci rate

Table.6 Nei's distance, index of differentiation for all genetic groups

\begin{tabular}{|l|l|l|l|l|l|l|}
\hline $\begin{array}{l}\text { Genetic } \\
\text { groups }\end{array}$ & Nei's distance & \multicolumn{3}{|l|}{ Indix of differentiation (Fst) } \\
\hline Group A & 0 & Group B & Group C & Group A & Group B & Group C \\
\hline Group B & 0.033 & 0 & & 0 & & \\
\hline Group C & 0.058 & 0.009 & 0 & $0.1321 * *$ & 0 & \\
\hline **. Significant at P $<0.01$ & & & $0.1549 * *$ & $0.1715^{* *}$ & 0 \\
\hline
\end{tabular}

**: Significant at $\mathrm{P}<0.01$ 
Fig.1 Nursery of Solanum aethiopicum sub sp Kumba

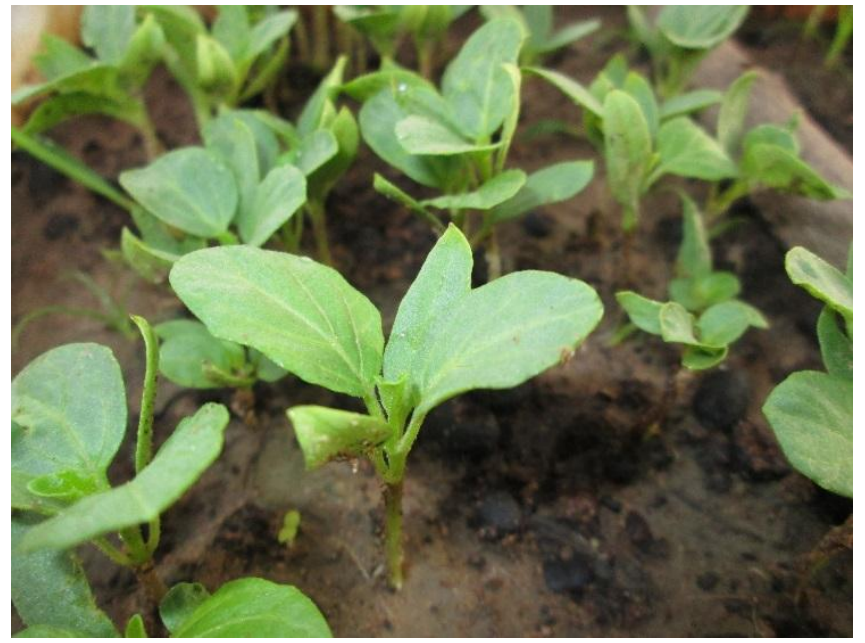

Fig.2 Dendrogram of all accessions constructed from the smSSR data using Neighbour-Joining method

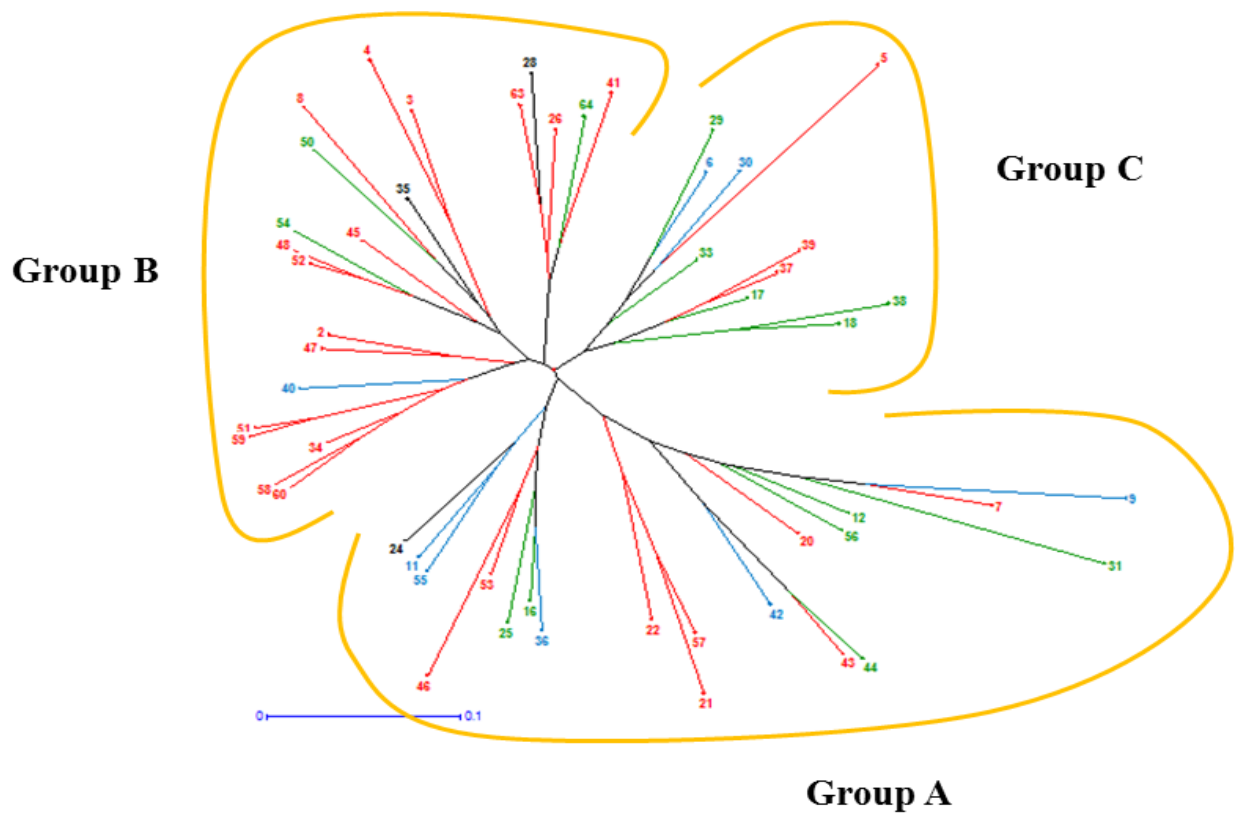

Three groups were formed (A, B and C) for the unrooted neighbor joining tree. Group $A$ has 20 accessions mainly comprises samples from the Sudano-sahelian zone and the improved variety KeurM'BirN'Dao. Group B was highly composite only of accessions from different climatic zones and improved varieties Meketan and N'Goyo. But the group $\mathrm{C}$, composite 10 accessions, and was the most balanced in terms of number of samples per climate zone (Figure 2).

\section{Genetic parameters for genetic groups}

The number of effective alleles varied from 1.592 (group A) to 1.485 (group C). The expected heterozygosity $\left(\mathrm{H}_{\mathrm{e}}\right)$ varied from 0.361 to 0.307 for groups $\mathrm{A}$ and $\mathrm{C}$ 
respectively. Finally, the Shannon diversity index and the polymorphism information content varied respectively from 0.513 to 0.404 and 0.348 to 0.267 for groups A and C respectively. In general, the diversity parameters were the highest in group A, but in group $\mathrm{C}$ it's the lowest (Table 5).

\section{Differentiation of genetic groups}

The minimal distance of Neiof genetic groups were the highest and varied from0.058 (group A and group C) to 0.009 (group B and group C). Moreover, index of differentiation index (Fst) revealed highly significant difference for genetic groups; it varied from 0.1391 (group A and group B) to 0.1715 (groups B and C). Therefore, group A was far to group C, but group B was near to group C (Table 6).

Moderate diversity has been observed in Kumba's collection of Burkina Faso. In Solanaceae, low diversity parameters on cultivars and intraspecific lines have already been reported by Smulders et al., (1997); Nunome et al., (2003a), Stagel et al., (2008) due to the preferential reproductive kind that is autogamous.

The rate of polymorphism of microsatellite markers tested was $65.5 \%$, it was quasi to value $(69.5 \%)$ reported by Nunome et al., (2003a) on $S$. melongena. The mean number of alleles (1.58) was lower than that (4.2) reported by Tumbilen et al., (2011), with the same markers used. Similarly, the mean number of effective alleles (1.699) and heterozygosity $(0.355)$ are the lowest to those reported by Nunome and al. (2003b, 2009) with the values 3.1 and 0.585 on $S$. melongena respectively. According to Ben Naceur et al., (2008), the number of alleles per locus was affected by several factors such as genotype, primer sequences as well as minor variations in amplification protocols. These differences were depended a both to the species studied and the nature of the markers tested. Indeed, the collection studied by Tumbilen et al., (2011) was diversified; there were revealed three culti groups of the species S. aethiopicum.

The EST-SSR markers used in this study were developed on $S$. melongena and amplified only the coding portions of the gene. According to Zhu et al., (2012), the diversity of a studied collection is lower when the used markers were developed on another species. Also, same recent studies shown on intraspecific diversity studied, that EST-SSRs markers gave the lowest diversity parameters to results of genomic SSR markers reported by Demir et al., 2010, Zhu et al., 2012 Caguiat and Hautea, 2014. However, the polymorphism's rate of each allele $(100 \%)$ shown that the used markers ability, revealed the genetic diversity of Kumba's collection, but that is lowest. Same results were reported by Adeniji et al., (2012) and Oppong et al., (2015) on the same genus Solanum. The value of the PIC (0.347) studied was higher than those of Caguiat and Hautea (2014) with mean PIC $=0.111$. The Shannon diversity index (0.808) recorded in this study is lower than that reported by Oppong et al., in 2015 (1.058) on $S$. aethiopicum. The size of the alleles varied from50 to $450 \mathrm{bp}$ include those values reported by Adeniji et al., (2013) and Ansari and Singh (2014), it was the same value similar to those reported by Nunome et al., (2003b; 2009) and Bationo-Kando et al., (2015b). The differences observed among the genotypes suggest the existence of sufficient inherent genetic variability among its. This variation can be exploited for further improvement of Kumba.

Despite the vast area of collection, the diversity revealed in this is the same value reported by Bationo-Kando et al., (2015b). In fact, the result of heterozygosity (0.347) in this study was reported by Bationo-Kando et 
al., (2015b) on accessions from west of Burkina Faso. At Burkina Faso, the diversity of Kumba could thus be revealed from a collection of one climatic zone. This result could be explained by the method of seed management and the migratory flow of population. Indeed, in this country, seed exchange amongst farmers has been reported by previous studies on vegetables (BationoKando et al., 2015a, Kiébre, 2016, Ouédraogo, 2016). According to Diouf et al., (2007), the exchange of seeds amongst farmers can lead to a migration of plant material over distances from 100 to $800 \mathrm{~km}$. was due to migration of plant material that permitted from 100 to $800 \mathrm{~km}$.

The random structuring of diversity, without reference to collection site (province or agroclimatic zone), reminded us of the existence of numerous duplicates in studied samples that is probably also in response to the management mode of the seed.

The massal selection carried out by the producers conduced to cultivate the same morphotypes in several localities. The improved control varieties used in this study are found in genetic Groups A and B. There are possibilities to select morphotypes that meet the criteria of consumer choice.

Molecular characterization using EST-SSR markers of African Eggplant of group Kumba grown in Burkina Faso shown moderate genetic variability within the collection. Although the collection included all the climatic zones and it presents a diversity similar to the collection of the western zone of Burkina Faso. The diversity of the Kumba of Burkina Faso can thus be highlighted by the one zone of collection. A structure of three genetic groups influenced lowly by the geographical origin of the accessions observed. Groups A and B with improved varieties could be used for the selection of corresponding varieties of producers and consumers.

\section{Acknowledgement}

To the valiant farmers who work constantly to preserve biodiversity and who have agreed to share their seeds and knowledge.

\section{References}

Adeniji O.T. and Aloyce A., 2012. Farmer's Knowledge of Horticultural Traits and Participatory Selection of African Eggplant Varieties (Solanum aethiopicum) in Tanzania. Tropicultura 30, 185-191.

Adeniji O.T., Kusolwa P. and Reuben S.W.O.M., 2013. Morphologicalde scriptors and microsatellite diversity among scarlet eggplant groups. African Crop Science Journal, Vol. 21, No. 1, pp. $37-49$.

Adeniji O.T., Kusolwa P., Reuben S.O.W.M. and Deo P., 2012. Molecular diversity among seven Solanum (eggplant and relatives) species assessed by simple sequence repeats (SSRs) markers. African Journal of Biotechnology, Vol. 11 (90): 15643-15653.

Ansari A.M. and Singh Y.V., 2014. Molecular diversity of brinjal (Solanum melongena L. and S. aethiopicum L.) genotypes revealed by SSR markers. Electronic Journal of Plant Breeding, 5(4): 722-728.

Bationo-Kando P., Nanema K.R., Kiébre Z., Sawadogo B., Kiébre M., Nébie B., Sawadogo N., Traoré R.E., Sawadogo M., and Zongo J.D., 2015b. Genetic diversity of cultivars of Kumba group (Solanum aethiopicum) assessed by EST-SSRS. International Journal of Development Research, Vol. 5, (10): 5686-5691.

Bationo-Kando P., Sawadogo B., Nanéma K. 
R., Kiébré Z., Sawadogo N., Kiébré M., Traoré R. E., Sawadogo M., Zongo J.D., 2015a. Characterization of Solanum aethiopicum (Kumba group) in Burkina Faso. International Journal of Sciences and Nature Vol.6 (2): 169-176 ISSN $2278-9103$.

Ben Naceur M., Belghouthi A., Chaabane R., Ben Salah H., El FelahM. et BettaïebBen Kaab L., 2008. L'aptitude des marqueurs SSR a révélé le polymorphisme chez quelques génotypes d'orge (Hordeumvulgare L). Ann. de l'INRAT, 61-75 pp.

Caguiat X.G.I. and Hautea D.M., 2014. Genetic Diversity Analysis of eggplant (Solanum melongena L.) and related wild species in the Philippines using morphological and SSR markers. SABRAO Journal of Breeding and Genetics, 46 (2) 183-201.

Daunay M.C., Lester R.N., Dalmon A., Ferri M., Kapilima W., Poveda-Aguilar M. and Jullian E., 1998. The use of wild genetic resources for eggplant (Solanum melongena) breeding. II. Crossability and fertility of interspecific hybrids. Proceedings 10th Eucarpia Meeting on Genetics and Breeding of Capsicum and Eggplants: 19-24.

Demir K., Bakır M., Sarıkamış G. and Acunalp S., 2010. Genetic diversity of eggplant (Solanum melongena) germplasm from Turkey assessed by SSR and RAPD markers. Genet. Mol. Res. 9 (3): 1568-1576.

Diouf M., Mbengue N.B. et Kante A., 2007. Caractérisation des accessions de 4 espèces de légumes feuilles traditionnels (Hibiscus sabdariffa L., Vigna unguiculata (L.) WALP, Amaranthus L. spp et Moringaoleifera LAM) au Sénégal. African Journal of food agriculture and nutrition 7, 1- 16.

Doyle J.J. and J.L. Doyle, 1990. A rapid total DNA preparation procedure for freshplant tissue. Focus 12:13-15.

Excoffier L., Smouse P.E. and Quattro J.M., 1992. Analysis of molecular variance inferred from metricdistances among DNA haplotypes: applicationto human mitochondrial DNA restriction data.Genetics, 131: 479-491.

Kiébré Z., 2015. Diversité génétique du caya blanc (Cleomegynandra L.) du Burkina Faso. Thèse Unique, Université de Ouagadougou (Burkina Faso), 148p.

Nunome T., Negoro S., Kono I., Kanamori H., Miyatake K., Yamaguchi H., Ohyama A. and Fukuoka H. 2009. Development of SSR markers derived from SSR-enriched genomic library of eggplant (Solanum melongena L.). Theor. Appl. Genet., 119:1143-1153.

Nunome T., Suwabe K., Iketani H. and Hirai M., 2003a. Identification and characterization of microsatellites in eggplant. Plant Breeding122: 256262.

Nunome T., Suwabe K., Ohyama A. and Fukuoka H., 2003b. Characterization of trinucleotide microsatellites in eggplant. Breed Sci., 53:77-83.

Oppong L.A., Quain M.D., Oppong A., Doku H.A., Agyemang A. and Offei Bonsu K., 2015. Molecular Characterization of Solanum Species Using EST-SSRs and Analysis of Their Zinc and Iron Contents. AJEA, 6(1): 30-44.

Ouédraogo M.H., 2016. Diversitégénétique $d u$ gombo (Abelmoschusesculentus $\mathrm{L}$. MOENCH) du Burkina Faso. Thèse de doct. Unique, Univ. Ouaga., 172p.

Sawadogo B., Bationo/Kando P., Sawadogo N., Kiébré Z., Kiébré M., Nanema K.R., Traoré R.E., Sawadogo M. and Zongo J.D., 2016. Variation, correlation and heritability of interest characters for selection of African eggplant. African Crop Science Journal, Vol. 24, No. 2, pp. $213-222$.

Smulders M.J.M., Bredemeijer G., Rus- 
Kortekaas W., Arens P. and Vosman B., 1997. Use of short microsatellites from database sequences to generate polymorphisms among Lycopersicon esculentum cultivars and accessions of other Lycopersicon species. Theor. Appl. Genet. 97, 264-272.

Stàgel A., Portis E., Toppino L., Rotino G.L. and Lanteri S., 2008. Gene-based microsatellite development for mapping and phylogeny studies in eggplant. BMC Genomics, 9: 357, 14p.
Tümbilen Y., Frary A., Daunay M.C. and Doğanlar S., 2011. Application of ESTSSRs to examine genetic diversity in eggplant and its close relatives. Turk. J. Biol., 35: 125-136.

Zhu X.C., Wu H.W., Raman H. and Lemerle D., 2012. Stanton R. and Burrows G.E., Evaluation of simple sequence repeat (SSR) markers from Solanum crop species for Solanum elaeagnifolium. Weed Research, 7p.

\section{How to cite this article:}

Sawadogo Boureima, Kiebre Zakaria, Bationo-Kando Pauline, Kiebre Mariam, Traore R. Ernest, Sawadogo Nerbéwendé, Nanema K. Romaric, Ouedraogo M. Hamed, Kabore Boukaré, Alleidi Issa et and Sawadogo Mahamadou. 2018. Evaluation of Genetic Diversity of African Eggplant [Solanum aethiopicum (L.) sub sp Kumba] Using EST-SSR Molecular Markers. Int.J.Curr.Microbiol.App.Sci. 7(02): 2470-2479. doi: https://doi.org/10.20546/ijcmas.2018.702.301 